\title{
HLA Class I-restricted Cytotoxic T Lymphocytes Specific for Hepatitis C Virus Identification of Multiple Epitopes and Characterization of Patterns of Cytokine Release
}

\author{
Margaret James Koziel, * Darnyll Dudley, * Nezam Afdhal, ${ }^{*}$ Arash Grakoui, ${ }^{\S}$ Charles M. Rice, $\$$ Qui-Lim Choo," \\ Michael Houghton," and Bruce D. Walker* \\ *Infectious Disease Unit, Massachusetts General Hospital and Harvard Medical School, Boston, Massachusetts 02114; ${ }^{\ddagger}$ Division of \\ Gastroenterology, Boston City Hospital and Boston University Medical School, Boston, Massachusetts 02118; ${ }^{\S}$ Department of Molecular \\ Microbiology, Washington University, St. Louis, Missouri 63110; and "Chiron Corporation, Emeryville, California 94608
}

\begin{abstract}
Cytotoxic T lymphocytes (CTL) are important to the control of viral replication and their presence may be important to disease outcome. An understanding of the spectrum of proteins recognized by hepatitis $\mathrm{C}$ virus (HCV)-specific CTL and the functional properties of these cells is an important step in understanding the disease process and the mechanisms of persistent infection, which occurs in the majority of $\mathrm{HCV}$-infected individuals. In this report we identify HCV-specific CTL responses restricted by the HLA class I molecules A2, A3, A11, A23, B7, B8, and B53. The epitopes recognized by these intrahepatic CTL conform to published motifs for binding to HLA class I molecules, although in some cases we have identified CTL epitopes for which no published motif exists. The use of vectors expressing two different strains of $\mathrm{HCV}, \mathrm{HCV}-1$ and $\mathrm{HCV}-\mathrm{H}$, revealed both strain-specific and cross-reactive CTL. These HCV-specific CTL were shown to produce cytokines including IFN- $\gamma$, TNF- $\alpha$, GM-CSF, IL-8, and IL-10 in an antigen- and HLA class I-specific manner. These studies indicate that the CTL response to $\mathrm{HCV}$ is broadly directed and that as many as five different epitopes may be targeted in a single individual. The identification of minimal epitopes may facilitate peptide-specific immunization strategies. In addition, the release of proinflammatory cytokines by these cells may contribute to the pathogenesis of $\mathrm{HCV}$-induced liver damage. (J. Clin. Invest. 1995. 96:2311-2321.) Key words: hepatitis $\mathrm{C}$ virus - epitopes - cytotoxic $\mathbf{T}$ lymphocytes $\cdot$ cytokines $•$ chronic hepatitis
\end{abstract}

\section{Introduction}

Infection with hepatitis $\mathrm{C}$ virus $(\mathrm{HCV})^{1}$ leads to chronic liver disease in $50-70 \%$ of infected individuals (1). In chronically

This work was presented in part at the 44th annual meeting of the American Society for Liver Disease in Chicago, IL, 1993.

Address correspondence to Margaret James Koziel, Infectious Disease Unit, Massachusetts General Hospital, Fruit Street, Boston, MA 02114. Phone: 617-724-7563; FAX: 617-726-7416.

Received for publication 29 August 1994 and accepted in revised form 6 July 1995.

1. Abbreviations used in this paper: aa, amino acid; B-LCL, B lymphoblastoid cell line; con A, concanavalin A; CTL, cytotoxic T lymphocytes; HBV, hepatitis B virus; HCV, hepatitis C virus; vv, vaccinia virus.

J. Clin. Invest.

(C) The American Society for Clinical Investigation, Inc.

0021-9738/95/11/2311/11 \$2.00

Volume 96, November 1995, 2311-2321 infected individuals, there is persistent viremia and liver damage despite the presence of both humoral $(2,3)$ and cellular immune responses (4-7). The mechanism of persistent infection despite such vigorous immune responses is unknown. In hepatitis B virus (HBV) infection, cytotoxic T lymphocytes (CTL) are present in the acute phase of hepatitis $(8,9)$ but their role in inhibition of viral replication is unknown. In the chronic hepatitis, the presence of virus-specific CTL is thought to lead to tissue destruction in the absence of control of viral replication (10).

Previously this laboratory has reported HLA class I-restricted CTL specific for the core, E1, E2, and NS2 proteins among liver-infiltrating lymphocytes of persons with chronic $\mathrm{HCV}$, establishing the existence of a CTL response to this virus in chronically infected humans $(4,5)$. In this report, we extend the findings regarding cellular immunity to HCV by demonstrating that multiple proteins may serve as targets for $\mathrm{HCV}$-specific CTL within the context of the immune response in an individual. Using vaccinia-HCV recombinant viruses which express two different strains of HCV, we have also identified CTL which recognize only one strain of $\mathrm{HCV}$, a finding which may have important implications for vaccine development.

Despite the broadly directed CTL response, CTL would be capable of killing only a minority of hepatocytes, since in most cases only a fraction of hepatocytes are infected with HCV (11). Recent studies in a transgenic mouse model of fulminant HBV infection have shown that production of IFN- $\gamma$ and TNF- $\alpha$ by virus-specific CTL may amplify the ability of the CTL to lyse infected cells (12). Production of IFN- $\gamma$ and TNF- $\alpha$ by murine HBV-specific CTL leads to the recruitment of large numbers of inflammatory cells, and also serves to inhibit viral replication (13). The production of cytokines, based on patterns of cytokine release and functional studies, by murine CD4 lymphocyte populations has been well characterized (reviewed in reference 14). The cytokines released by human CD8 + CTL have been less well characterized, and may be important to our understanding of the balance between the tissue destruction initiated by virusspecific CTL and their role in controlling viral replication (15). Previously this laboratory has reported the production of IFN$\gamma$, TNF- $\alpha$, and TNF- $\beta$ by HIV- 1 -specific CTL (16). In this report we extend these findings to show that $\mathrm{HCV}$-specific CTL produce additional cytokines, including GM-CSF, IL-8, and, in some cases, IL-10 upon recognition of target cells.

\section{Methods}

Subjects. HCV-seropositive subjects with evidence of chronic liver disease (at least fourfold elevations in serum transaminases for at least 6 mo) underwent liver biopsy by modified Klatskin technique before $\alpha$ IFN therapy. All subjects were HBV and HIV-1 seronegative, and had evidence of mild to moderate chronic active hepatitis on histologic examination of liver tissue. All subjects gave informed consent, and the 


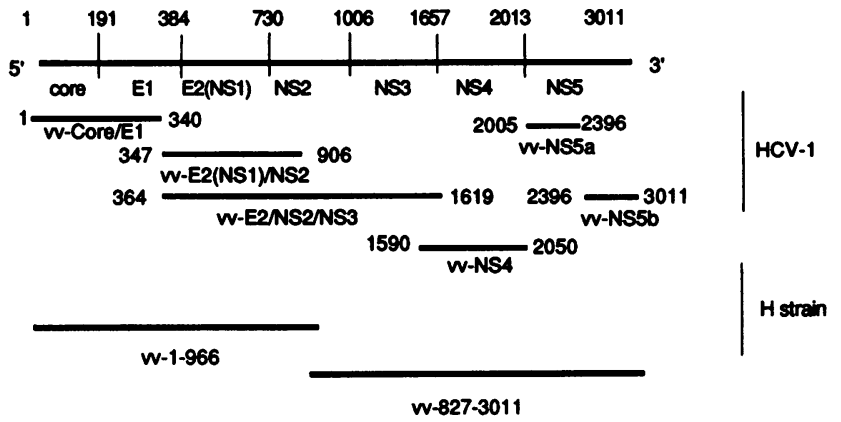

Figure 1. Schematic representation of vaccinia virus constructs used in this study.

study was approved by the Massachusetts General Hospital Human Studies Committee. Subjects were coded by year of receipt of the specimen in the laboratory and lettered sequentially. Peripheral blood for EBV transformation, HLA typing, and expansion of CD8+ cells was obtained at the time of liver biopsy.

Cell lines. EBV-transformed B-lymphoblastoid cell lines (B-LCL) were established and maintained as described previously (17) in RPMI 1640 media (Sigma Chemical Co., St. Louis, MO) supplemented with $2 \mathrm{mM}$ L-glutamine, $50 \mathrm{U} / \mathrm{ml}$ of penicillin, $50 \mu \mathrm{g} / \mathrm{ml}$ of streptomycin, and $10 \mathrm{mM}$ Hepes, in addition to $20 \%$ heat-inactivated FCS (R-20 medium). Additional B-LCL were obtained from the American Society for Histocompatibility and Immunogenetics B cell line repository.

HLA typing. HLA typing of subjects was performed on fresh PBMC by the Massachusetts General Hospital Tissue Typing Laboratory, using standard serologic techniques.

Vaccinia virus constructs. Vaccinia-HCV recombinant viruses were constructed to express the structural and nonstructural proteins of the HCV (see Fig. 1; reference 18-20 and Choo, Q.-L., unpublished data). Insertion of genomic sequences coding for the $\mathrm{HCV}$ proteins was achieved by ligation of the nucleotide sequences into the pSC11 vector by standard techniques (21). Vaccinia virus (vv)-C/E1 expresses amino acids (aa) $\mathrm{Met}_{1}-\mathrm{Ile}_{340}$ of $\mathrm{HCV}$, which comprise the core (C) and E1 proteins; and vv-E2/NS2/NS3 expresses aa $\mathrm{Met}_{364}-\mathrm{His}_{1619}$, which comprise the carboxy terminus of E2, NS2, and NS3 proteins of HCV (18, 19). vv-E2/NS2 expresses aa MET $347-\mathrm{Leu}_{906}$. After the screening of 92T cells was complete, additional vaccinia constructs became available. To express structural and non-structural proteins of another strain, additional $\mathrm{vv}$ which express proteins of the $\mathrm{H}$ strain were also used. $\mathrm{vv}-1$ 966(H) expresses aa $\mathrm{Met}_{1}-\mathrm{Asp}_{966}$ of the $\mathrm{H}$ strain polyprotein (Grakovi, A. and C. M. Rice, unpublished data). vv-827-3011(H) expresses aa $\mathrm{Met}_{827}-\mathrm{Arg}_{3011}$ of the $\mathrm{H}$ strain polyprotein (20). After the screening of 93I, vv-NS4, which expresses $\mathrm{Gly}_{1590}-\mathrm{Lys}_{2050}$ of HCV-1, and vv-NS5A and NS5B, which express $\mathrm{Gly}_{2005}-\mathrm{Gly}_{2396}$ and $\mathrm{Gly}_{2396}-\mathrm{Arg}_{3011}$ of HCV1 , respectively, became available $(20,22)$. A vv expressing only the Escherichia coli $\beta$-galactosidase gene $(v v$-Lac) was used as a control (21). All vaccinia-HCV recombinant viruses were demonstrated to express the appropriate HCV proteins by radioimmunoprecipitation (18, 20 , and unpublished data).

Synthetic peptides. Synthetic peptides corresponding to the aa sequences of the HCV-1 strain of Choo et al. (23) were synthesized as free acids by Cambridge Research Biochemicals (Cambridge, MA) using the Fmoc method (24). Peptide 1 corresponds to aa 1-20, and adjacent serial peptides overlap by 10 aa. For aa 906-1619, the overlapping peptides were 13 aa in length and overlapped by 10 aa. Synthetic peptides spanning the NS5B region were synthesized based on the amphipathic profile of residues spanning this region (reference 25, kindly provided by Dr. Jay Berzofsky, NIAID). Fine mapping was achieved using additional smaller peptides in free acid form which were purchased commercially (IDEC Pharmaceuticals, La Jolla, CA) or synthesized on an automated peptide synthesizer (model 482A, Applied Biosystems, Inc. Foster City, CA). All peptides were reconstituted in sterile distilled water containing $10 \%$ DMSO (Sigma Chemical Co.) and $1 \mathrm{mM}$ dithiothreitol (Sigma Chemical Co.).

Cloning of liver-infiltrating lymphocytes. CD8+ liver-infiltrating lymphocytes were expanded from the liver biopsy specimens as described $(4,5)$, using the bispecific monoclonal antibody CD3,4B (reference 26, kindly supplied by Dr. Johnson Wong, Massachusetts General Hospital, Boston, MA). $1 \times 10^{6}$ of the expanded cells were restimulated with $4 \mathrm{ml}$ of feeder cell suspension, which consisted of $10^{6} \mathrm{cells} / \mathrm{ml}$ of irradiated ( $30 \mathrm{Gy)}$ allogeneic PBMC in R-10 media supplemented with $100 \mathrm{U} / \mathrm{ml}$ of recombinant IL-2 (rIL-2), and were tested for HCV-specific cytolytic activity on day 10 . If screening of these expanded CD8+ lymphocytes showed HCV-specific cytolytic activity (arbitrarily defined as $>20 \%$ specific lysis), cells were cloned at limiting dilution as described (5). Developing cells were selected from 96-well plates in which $<33 \%$ of the cells displayed visible growth. These cells were restimulated with irradiated feeder cells and the anti-CD3 monoclonal antibody 12F6 as described (17), and then tested for HCV-specific cytolytic activity. No cells were detected with specificity for more than one HCV protein, and maintained specificity over prolonged periods of in vitro culture in the absence of specific antigenic stimulation, the cells are operationally are referred to as lines $(5,17)$.

Cytotoxicity assay using vaccinia-infected target cells. B-LCL were infected with either recombinant vaccinia-HCV vectors or a control vaccinia virus at a multiplicity of infection of 5-10 plaque-forming units (pfu)/cell, incubated overnight at $37^{\circ} \mathrm{C}$ in $5 \% \mathrm{CO}_{2}$, labeled with $\mathrm{Na}_{2}\left({ }^{51} \mathrm{CrO}_{4}\right)$ and used as target cells $\left(5 \times 10^{3}\right.$ cells/well $)$ in a chromium release assay (27). Supernatants were harvested at $4 \mathrm{~h}$, and percent specific cytotoxicity was determined by the formula [(release in assay - spontaneous release)/(maximum release - spontaneous release)] $\times 100$. Assays were excluded from analysis if the spontaneous release value was $>30 \%$. Results are reported as the mean of triplicate values, with a standard deviation of $<5 \%$.

Cytotoxicity assay using synthetic peptide-sensitized target cells. BLCL were pelleted and resuspended in fresh R-20 and labeled overnight with ${ }^{51} \mathrm{Cr}$. Cells $\left(1 \times 10^{6}\right)$ were then resuspended in $0.2 \mathrm{ml}$ of R-10 and peptide was added; after a $1-\mathrm{h}$ incubation at $37^{\circ} \mathrm{C}$, cells were washed three times and used as targets in the cytotoxicity assay. The concentration of peptides for screening ranged from $100-300 \mu \mathrm{g} / \mathrm{ml}$ unless otherwise indicated. For screening of large numbers of peptides in some assays, B-LCL were simultaneously sensitized with two noncontiguous peptides, a method which gave equivalent results to screening with individual peptides (data not shown).

For fine mapping experiments, results are shown using the lines that grew best in long term culture. For these experiments, B-LCL were labeled with ${ }^{51} \mathrm{Cr}$, washed three times, and then incubated with the indicated concentration of peptide in a 96-well plate. After a 1-h incubation, effector cells were added to the wells, and the supernatant was harvested at $4 \mathrm{~h}$.

Cytokine release assay. Effector cells were incubated with $10^{5}$ peptide-sensitized target cells per well in 96-well U-bottom plates in a total volume of $200 \mu \mathrm{l}$ of R-10 medium for $24 \mathrm{~h}$ at $37^{\circ} \mathrm{C}$ in a $5 \% \mathrm{CO}_{2}$ chamber. Previous studies (16) had demonstrated that peak cytokine release was at $24 \mathrm{~h}$, when measured at $4,6,24$, and $48 \mathrm{~h}$. Since B-LCL may constitutively produce cytokines (16), target cells were irradiated with $100 \mathrm{~Gy}$ before incubation with the effector cells. No difference was detected in measurement of cytokines performed with irradiated and nonirradiated target cells (reference 16, and data not shown). Additional controls consisted of effector cells alone cultured in the presence of 5 $\mu \mathrm{g} / \mathrm{ml}$ of concanavalin A (conA) and target cells incubated with peptide alone for $24 \mathrm{~h}$ and then lysed with $1 \%$ Triton X-100 before measurement of cytokine release. Lines were tested for cytokine release at an $\mathrm{E} / \mathrm{T}$ of 1:1. Supernatant fluid was harvested and stored at $-70^{\circ} \mathrm{C}$ until testing for specific cytokine release. Commercially available enzyme-linked immunoabsorbent assays were performed according to manufacturer's instructions. ELISA assays were obtained commercially from Endogen (TNF- $\alpha$, IL-10, GM-CSF, IFN- $\gamma$; Boston, MA); Bender MedSystems (IL-8; Vienna, Austria); and Innogenetics (IL-4 and IL-6; Antwerp, Belgium). Chromium release assays were performed in parallel with all cytokine release assays to serve as a control for virus specific killing. 


\begin{tabular}{|c|c|c|c|c|c|c|c|c|c|}
\hline \multirow[b]{2}{*}{ CTL line } & \multirow[b]{2}{*}{$E / T$} & \multicolumn{7}{|c|}{ \% Specific lysis of target cells expressing (aa): } & \multirow[b]{2}{*}{ Lac } \\
\hline & & C/E1 & $\mathrm{E} 2 / \mathrm{NS} 2$ & $\mathrm{E} 2 / \mathrm{NS} 2 / \mathrm{NS} 3$ & NS4 & NS5b & $1-966(\mathrm{H})$ & $827-3011(\mathrm{H})$ & \\
\hline & & $(1-340)$ & $(347-906)$ & $(364-1619)$ & $(1590-2050)$ & $(2396-3011)$ & $(1-966)$ & $(827-3011)$ & \\
\hline $92 \mathrm{~T}-11$ & $2.5: 1$ & 3.0 & 32 & 31.2 & nt & nt & nt & nt & 1.1 \\
\hline $92 \mathrm{~T}-18$ & $20: 1$ & 4.9 & 20 & 48.9 & nt & nt & nt & nt & 3.1 \\
\hline $92 \mathrm{~T}-24$ & $2.5: 1$ & 0.5 & 26.1 & 32.8 & nt & nt & nt & nt & 1.2 \\
\hline $92 \mathrm{~T}-32$ & $2.5: 1$ & 0.1 & 17.2 & 18.4 & nt & nt & nt & nt & 0.4 \\
\hline $92 \mathrm{~T}-51$ & $10: 1$ & 0.1 & 11.0 & 22.5 & nt & nt & nt & nt & 0.4 \\
\hline $92 \mathrm{~T}-92$ & $10: 1$ & -0.5 & 10.3 & 21.4 & nt & nt & nt & nt & 0.7 \\
\hline $93 \mathrm{I}-8$ & $5: 1$ & 0 & 55 & 64.9 & nt & $\mathrm{nt}$ & 0 & 0 & 1.6 \\
\hline $93 I-16$ & $10: 1$ & 0 & 0 & 0 & 0 & 45.7 & 0 & 37.9 & -0.2 \\
\hline 93I-58 & $10: 1$ & 26.0 & 0 & 0.7 & $\mathrm{nt}$ & $\mathrm{nt}$ & 26.8 & 0 & 1.9 \\
\hline 93I-72 & $5: 1$ & 21.5 & 0 & 0 & nt & nt & 30.4 & 0 & 3.3 \\
\hline 93I-99 & $2: 1$ & 21.0 & 0 & 0 & nt & $\mathrm{nt}$ & $\mathrm{nt}$ & 0 & 0.8 \\
\hline 93K-33 & $2.5: 1$ & 0 & 1.2 & 26.9 & $\mathrm{nt}$ & nt & $\mathrm{nt}$ & 27.5 & 0 \\
\hline 94F-5 & $10: 1$ & 3.0 & 33.6 & 37.4 & 0 & 0 & 17.5 & 0 & -0.6 \\
\hline 94F-35 & $10: 1$ & 0 & 63.8 & 59.2 & 0 & 0 & 28.5 & 0 & 2.7 \\
\hline $94 \mathrm{~F}-46$ & $1: 1$ & 0 & 50.2 & 55.5 & nt & $\mathrm{nt}$ & 0 & 0 & 1.0 \\
\hline $94 \mathrm{~F}-65$ & $10: 1$ & 0 & 0 & 61.7 & 3.5 & $\mathrm{nt}$ & 4.7 & 49.6 & 1.0 \\
\hline $94 \mathrm{~F}-69$ & $5: 1$ & 0 & 0 & 0 & 3.9 & 59.9 & 0 & 51.6 & 1.0 \\
\hline $94 \mathrm{~F}-86$ & $20: 1$ & 0 & 1.2 & 56.7 & 4.9 & $\mathrm{nt}$ & 0 & 51.2 & 1.2 \\
\hline
\end{tabular}

HCV-specific cytolytic activity of CTL derived from liver infiltrating lymphocytes of four HCV-seropositive subjects with chronic hepatitis was tested in a standard 4-h ${ }^{51} \mathrm{Cr}$-release assay. Autologous B-LCL infected with HCV recombinant vaccinia viruses were used at target cells. nt, not tested.

Results shown are representative of at least two, and usually three, independent cytotoxicity assays with cytokine measurements performed on two separate assays.

\section{Results}

Multiple $H C V$ antigens are recognized by CTL within liverinfiltrating lymphocytes. Liver-infiltrating lymphocytes were expanded in the presence of rIL-2 and irradiated allogeneic feeder cells, as well as a bispecific monoclonal antibody which results in the proliferation of CD8+ lymphocytes. After expansion of the CD8+ lymphocytes from the biopsy specimen, these cells were then cloned in the presence of a CD3-specific monoclonal antibody, rIL-2, and irradiated allogeneic feeder cells. At no time were lines derived from liver-infiltrating lymphocytes exposed to exogenous HCV antigens in vitro. Developing cells were tested for $\mathrm{HCV}$-specific cytolytic activity. In four subjects, HCV-specific CTL were found that recognized target cells infected with recombinant vaccinia-HCV viruses and grew in sufficient numbers to perform multiple assays on multiple dates (Table I). For subjects 92T and 93K-33, CTL responses against only one protein were identified. For subjects $93 \mathrm{I}$ and $94 \mathrm{~F}$, multiple proteins were recognized by CD8 + CTL. In the case of $94 \mathrm{~F}$, some CTL, including $94 \mathrm{~F}-5$ and $94 \mathrm{~F}-35$, recognized target cells expressing HCV-1 E2/NS2/NS3 and H strain 1966 , indicating that the epitope recognized by these cells lies within aa 364-906. Another line, 94F-65, was identified which recognized target cells expressing HCV-1 E2/NS2/NS3 and H strain 827-3011, but not $\mathrm{H}$ strain 1-966, which suggested that the epitope recognized by this line lies within aa 966-1619. Another CTL, 94F-69, was shown to recognize target cells expressing the HCV-1 NS5B as well as target cells expressing $\mathrm{H}$ strain, 827-3011, indicating recognition of an epitope in NS5. Additional lines were also identified within the liver-infiltrating lymphocytes of subject $94 \mathrm{~F}$. 94F-46 recognized only target cells expressing HCV-1 E2/NS2/NS3, but not the corresponding proteins of the $\mathrm{H}$ strain. Similarly, 94F-86 recognized target cells expressing $\mathrm{HCV}-1 \mathrm{E} 2 / \mathrm{NS} 2 / \mathrm{NS} 3$ and $\mathrm{H}$ strain 827-3011, but not HCV-1 E2/NS2 or the H strain construct vv-1-966(H), suggesting that the epitope recognized by this CTL lies between aa $906-1619$ but was a different epitope than that recognized by CTL lines $94 \mathrm{~F}-5$ and $94 \mathrm{~F}-35$. We did not identify any lines which recognized target cells expressing HCV-1 NS4 in this study.

We were unable to detect HCV-specific cytolytic activity within expanded CD8 + liver-infiltrating lymphocytes in another 12 subjects studied during this time period; and 2 additional subjects had HCV-specific activity within expanded CD8+ liver-infiltrating lymphocytes, but we were unable to isolate HCV-specific CTL lines which grew well enough in long term culture sufficient to perform multiple assays or identify the precise epitope recognized by these cells. Thus 6 out of 15 subjects studied during this time period had evidence of $\mathrm{HCV}$ specific CTL that recognized either HCV-1 or the $\mathrm{H}$ strain within the CD8+ liver-infiltrating lymphocytes. Recombinant vaccinia virus expressing the nonstructural proteins were only available for the latter half of the study. All HCV-specific lines were confirmed to be $\mathrm{CD} 8+$ by $\mathrm{FACS}^{\circledR}$ analysis (data not shown).

$H C V$-specific CTL are restricted by HLA class I molecules. CD8 + CTL recognize virally infected cells through interaction of the $\mathrm{T}$ cell receptor with a trimolecular complex consisting of a viral peptide fragment, MHC class I molecule, and beta 2 microglobulin (28). To further define the characteristics of the 

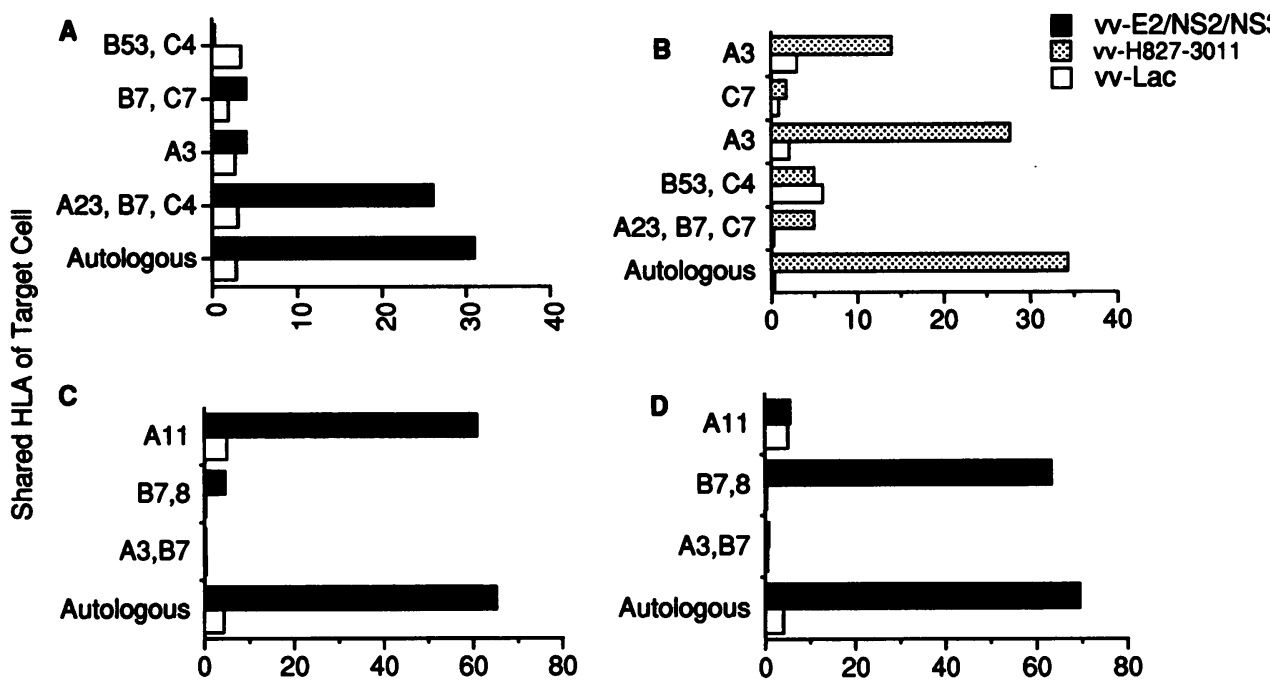

$\%$ Specific Lysis
Figure 2. HCV-specific CTL are HLA class I restricted. Lines were tested for their ability to lyse autologous and allogeneic target cells expressing $\mathrm{HCV}$ antigens. Target cells were infected with the vv construct expressing the relevant antigen as well as the control vv-lac. Shared HLA molecules are shown. (A) Line 93I-8 recognized target cells expressing E2/NS2/ NS3 in the context of HLA A23. The E/T was 5:1 $(B)$ Line 93I-16 recognized target cells expressing the H strain NS3/NS4/NS5 in the context of HLA A3. The E/T was 5:1 (C) Line 94F-35 recognized target cells expressing E2/NS2/ NS3 in the context of HLA A11. The E/T was 5:1 (D) Line 94F65 recognized target cells expressing E2/NS2/NS3 in the context of HLA B8. The E/T was 5:1. The complete HLA type of subject 931 is A2, 23; B 7, 53: C4,5: DR 8,13: DRw52, DQ 1,7. The complete HLA type of subject $94 \mathrm{~F}$ is $\mathrm{A} 3$, 11; B7,8; C7, Bw 6; DR 3,15; DRw52; DQ1,2. observed HCV-specific cytolytic activity, selected CTL lines were tested for their ability to lyse allogeneic target cells expressing HCV antigens. The HCV-specific cytotoxic effector cells recognized allogeneic target cells only in the context of a shared HLA class I molecule, with different HLA molecules restricting recognition of different $\mathrm{HCV}$ antigens. Examples are shown in Fig. 2. For example, the line 93I-8 recognized target cells expressing HCV-1 E2/NS2/NS3 only in the context of a shared HLA A23 molecule, whereas for CTL 94F-35, recognition was only present if HLA A11 was expressed. For line 94F65, which also recognized target cells expressing HCV-1 E2/ NS2/NS3, target cells were recognized only if HLA B8 was expressed. The HLA restricting element of the other HCVspecific CTL identified are summarized in Table II. If multiple lines were identified in a single subject which recognized target cells expressing the same HCV proteins and shared the same HLA restriction, in general confirmation studies were done with

Table II. Summary of HLA Restriction and Epitope Mapping of $C T L$

\begin{tabular}{lclc}
\hline CTL line & HLA restriction & Epitope recognized & aa \\
\hline 92T-32 & B53 & RPLTDFDQGW & $460-469$ \\
$93 \mathrm{I}-8$ & A23 & YISWCLWW & $838-845$ \\
93I-16 & A3 & RVCEKMALY & $2588-2596$ \\
93I-58 & B7 & GPRLGVRAT & $41-49$ \\
93K-33 & A2 & CINGVCWTV & $1073-1081$ \\
94F-35 & A11 & TINYTIFK & $621-628$ \\
94F-65 & B8 & HSKKKCDEL & $1395-1403$ \\
94F-69 & A3 & NS5B & not defined \\
& & & \\
\hline
\end{tabular}

AA are numbered according to reference 23 . a single representative CTL line which grew well in long term culture. These studies show not only that multiple proteins are recognized by HCV-specific CTL, but that multiple HLA molecules may participate in the presentation of $\mathrm{HCV}$ proteins for recognition by $\mathrm{HCV}$-specific CTL.

HCV-specific CTL recognize 8-10 aa epitopes in structural and nonstructural proteins. Peptide fragments presented to class I-restricted CTL are typically 8-10 aa in length (29). Incubating target cells with synthetic peptide has been shown to bypass the normal requirements for endogenous processing of viral peptide into fragments of the appropriate length (29), and thus enables definition of the epitopes recognized by virus-specific CTL. Overlapping 13-20 aa synthetic peptides spanning the appropriate viral proteins were used to map the regions containing epitopes recognized by the HCV-specific CTL. Once a region was identified, amino and carboxy terminal truncations of the peptide containing this region were synthesized and used to sensitize target cells for lysis. These results are shown in Figs. 3-8.

As shown in Fig. 3, the HLA B53-restricted CTL 92T32 recognized target cells infected with vv-E2/NS2/NS3 and uninfected target cells incubated with a synthetic peptide corresponding to aa 451-470, but not aa $441-460$ or aa $461-480$. None of the other 54 peptides which spanned the proteins of interest sensitized target cells for lysis (data not shown). Further studies utilizing amino and carboxy terminal truncations of this region showed that the epitope was in the 10 aa sequence RPLTDFDQGW (aa 460-9), which is in E2.

In a similar manner as was used for mapping of line 92T32 , the minimum peptide which could sensitize target cells for lysis for the HLA A23-restricted CTL line 93I-8, was the NS2 sequence YISWCLWW (aa 838-845) (Fig. 4). Other than the peptide which spanned aa 831-850, none of the other 54 peptides which spanned the proteins of interest sensitized target 


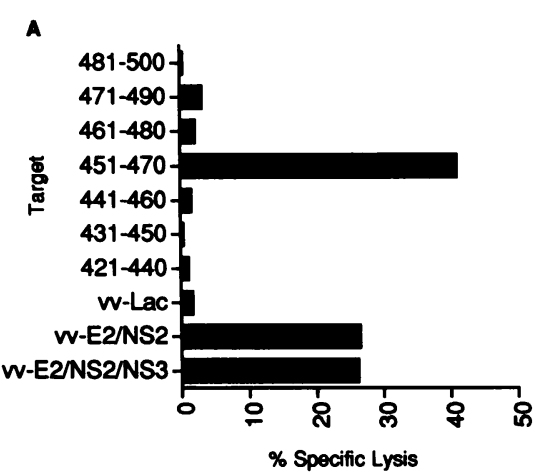

B

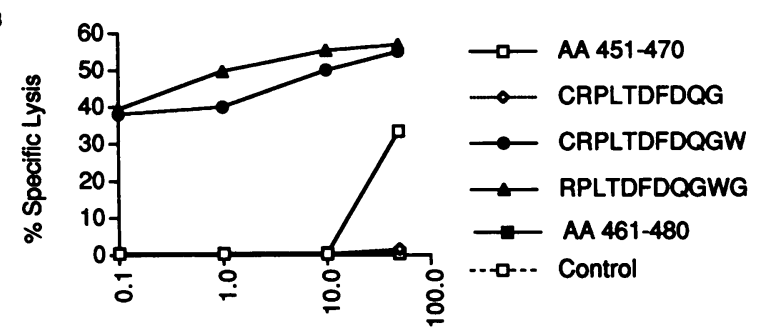

Conc Peptide (UM)

Figure 3. Mapping of the CTL epitope recognized by the HLA B53restricted CTL clone 92T-32. (A) Line 92T-32 was tested for its ability to lyse target cells sensitized with 20 aa peptides spanning the E2 and NS2 proteins. This clone recognized only target cells sensitized with the peptide spanning aa 451-470 (GCPERLASRCRPLTDFDQGWG), but not target cells sensitized with the overlapping peptide spanning 461-480 (PLTDFDQGWGPISYANGSGPD). Lysis of target cells infected with recombinant $v v$ is shown as a control. The E/T was 5:1 and the concentration of peptide used for sensitization of target cells was $100 \mu \mathrm{g} / \mathrm{ml}$. (B) Line $92 \mathrm{~T}-32$ was also tested for its ability to lyse autologous target cells incubated with amino and carboxy terminal truncations of the region unique to this peptide. 10-fold serial dilutions of the amino and carboxy terminal truncations of peptide 46 were incubated with target cells, and clone 92T-32 was tested for its ability to lyse target cells. The data indicate the epitope was in 10 aa sequence RPLTDFDQGW (aa 460-9), which is in E2. The E/T was 5:1.

cells for lysis (data not shown). Target cells sensitized with peptides lacking either the tyrosine (ISWCLWWLQ) or the carboxy terminal tryptophan (RYISWCLW) were unable to sensitize target cells for lysis (data not shown). The B7-restricted epitope recognized by the core-specific line 93I-58 lies within the overlap of two adjacent peptides spanning aa 31-50 and aa 41-60 (Fig. 5). Fine mapping of this sequence within the HCV core protein showed that optimal recognition was achieved with the sequence GPRLGVRAT (aa 41-49), as evidenced by the ability of this peptide to sensitize target cells for lysis at the lowest concentration of peptide.

Overlapping peptides representing either the HCV-1 or the $\mathrm{H}$ strain were not available for fine mapping of the epitope recognized by line 93I-16 (Fig. 6). However, synthetic peptides which contain potential $T$ cell epitopes on the basis of the amphipathicity profile of NS5B were available (reference 30 , generously provided by Dr. J. Berzofsky). These peptides are partially overlapping and have been used to map an epitope recognized by murine HCV-specific CTL (25). The HLA A3restricted line 93I-16 recognized target cells sensitized with the peptide spanning aa 2588-2596 (RVCEKMALY), which is consistent with the proposed motif for HLA A3 of a hydrophobic aa at position 2 and a tyrosine or lysine at position
A
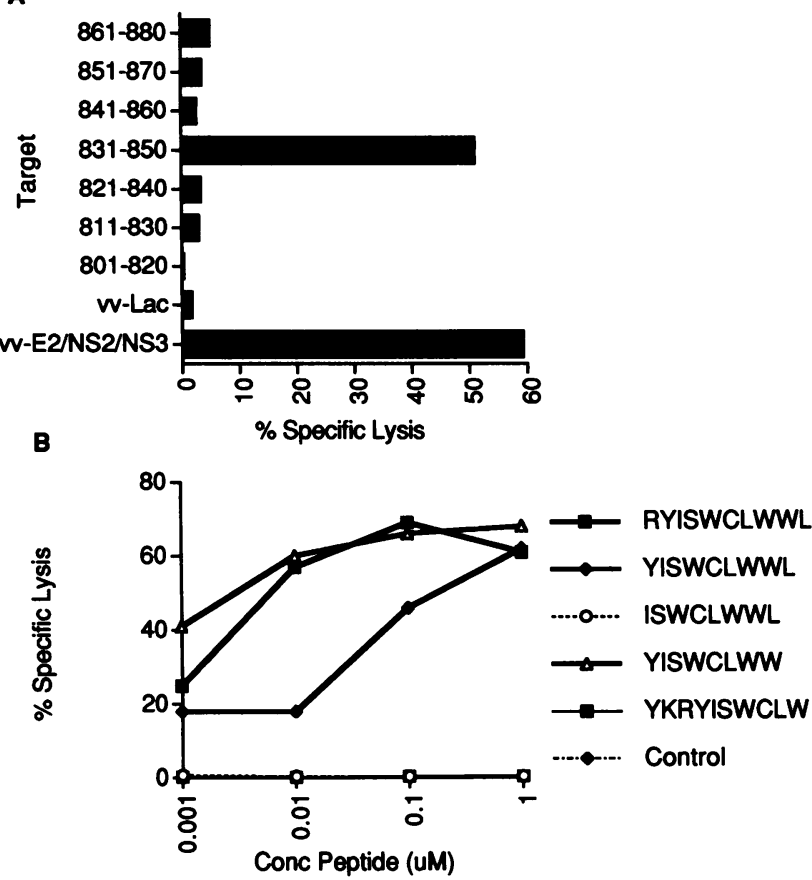

Figure 4. Mapping of the CTL epitope recognized by the HLA A23restricted CTL clone 93I-8. (A) Line 93I-8 was tested for its ability to lyse target cells sensitized with 20 aa peptides spanning the E2 and NS2 proteins. This clone recognized only target cells sensitized with peptide spanning aa 831-850 (LSPYYKKYISWCLWWLQYFL), but not peptides spanning aa 821-840 or 841-860. Lysis of target cells infected with recombinant $v v$ is shown as a control. The E/T was $5: 1$ and the concentration of peptide used for sensitization of target cells was 50 $\mu \mathrm{g} / \mathrm{ml}$. (B) Line 93I-8 was tested for its ability to lyse autologous cells sensitized with amino and carboxy terminal truncation of this peptide. Serial 10-fold dilutions of the amino and carboxy terminal truncations of aa 831-850 were incubated with target cells, and clone 93I-8 was tested for its ability to lyse target cells sensitized with these truncations. The minimum peptide which could sensitize target cells for lysis was YISWCLWW (aa 838-845). A peptide spanning aa 491-500 (PKPCGIVPAK) was used as a negative control. The E/T was $1: 1$.

9 (31). Since these peptides are not overlapping and not all aa of NS5B are represented, the presence of another A3 epitope cannot be completely excluded.

CTL 94F-35 recognized target cells expressing HCV-1 E2/ NS2/NS3 and H Strain 1-966, as well as HCV-1 E2/NS2 (Table I), and was tested for the ability to recognize target cells incubated with peptides spanning the region overlapped by these constructs, aa 347-966 (Fig. 7). Only the two peptides shown (aa 621-640 and 631-650) but none of the other 54 peptides which spanned the proteins of interest sensitized target cells for lysis (data not shown). The peptide TINYTIFK (aa 621-8), which lies within the E2, was able to sensitize target cells for lysis whereas loss of the amino terminal threonine or the carboxy terminal lysine abrogated recognition of target cells.

The HLA B8-restricted epitope recognized by line 94F-65 was identified using 15 aa peptides, which overlapped by 10 aa, spanning aa 966-1619. Only 3 of the 240 peptides which spanned the proteins of interest sensitized target cells for lysis. Fine mapping with smaller peptides revealed that the peptide HSKKKCDEL (aa 1395-1403) was optimal for sensitization of target cells, whereas peptides SKKKCDEL or HSKKKCDE failed to sensitize target cells (Fig. 8). This corresponds to the 

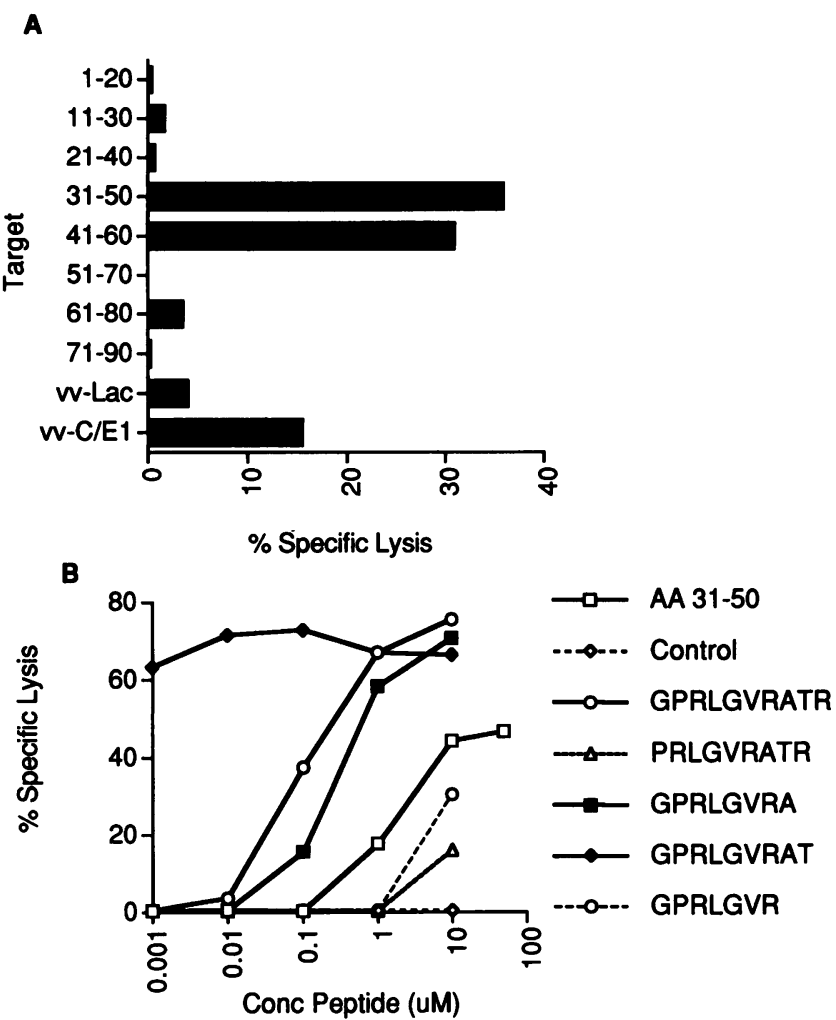

Figure 5. Mapping of the CTL epitope recognized by the HLA B7restricted clone 93I-58. (A) Line 93I-58 was tested for its ability to lyse autologous target cells individually incubated with synthetic 20 aa HCV peptides spanning the core and E1 proteins. This clone recognized target cells sensitized with either of two adjacent core peptides (aa 31 50, VGGVYLLPRRGPRLGV RATR; and 41-60, GPRLGVRATRKTSFRSQPRG); suggesting that the epitope was contained in the region overlapped by the two peptides, aa 41-50 (GPRLGVRATR). The E/ $T$ was 2:1, and the concentration of peptide used for sensitization of target cells was $20 \mu \mathrm{g} / \mathrm{ml}$. (B) Amino and carboxy terminal truncation of the overlap region were tested for their ability to sensitize target cells for lysis. Serial 10-fold dilutions of peptide were incubated with target cells, and clone 93I-58 was tested for recognition. Optimal recognition was achieved with the sequence GPRLGVRAT (aa 41-50). A peptide spanning aa 833-842 (PYYKRYISWC) was used as a negative control. The E/T was 1:1.

proposed motif for binding to HLA B8, with a lysine at position 3 and 5 and a leucine at the carboxy terminus (32). For the NS5B-specific CTL line 94F-69, fine mapping could not be determined because the available peptides spanning NS5B failed to sensitize target cells for lysis. The HLA A2-restricted CTL line 93K-33 was also identified using the same set of 240 peptides that span the NS3 protein. As shown in Fig. 9, only a single peptide spanning aa 1071-1085, sensitized target cells for lysis. Further definition of the epitope (Fig. $9 B$ ) recognized by this line showed that the peptide CINGVCWTV (aa 10731081) was optimal for sensitization of target cells. This conforms to the proposed motif for binding to the HLA A2.1 molecule, with an isoleucine at position 2 and a valine at the carboxy terminus (33). Moreover, some synthetic peptides which reflect natural variants of this epitope were not able to sensitize target cells for lysis (Fig. $9 \mathrm{C}$ ), indicating that aa substitutions within this CTL epitope might affect recognition by HCV-specific CTL.
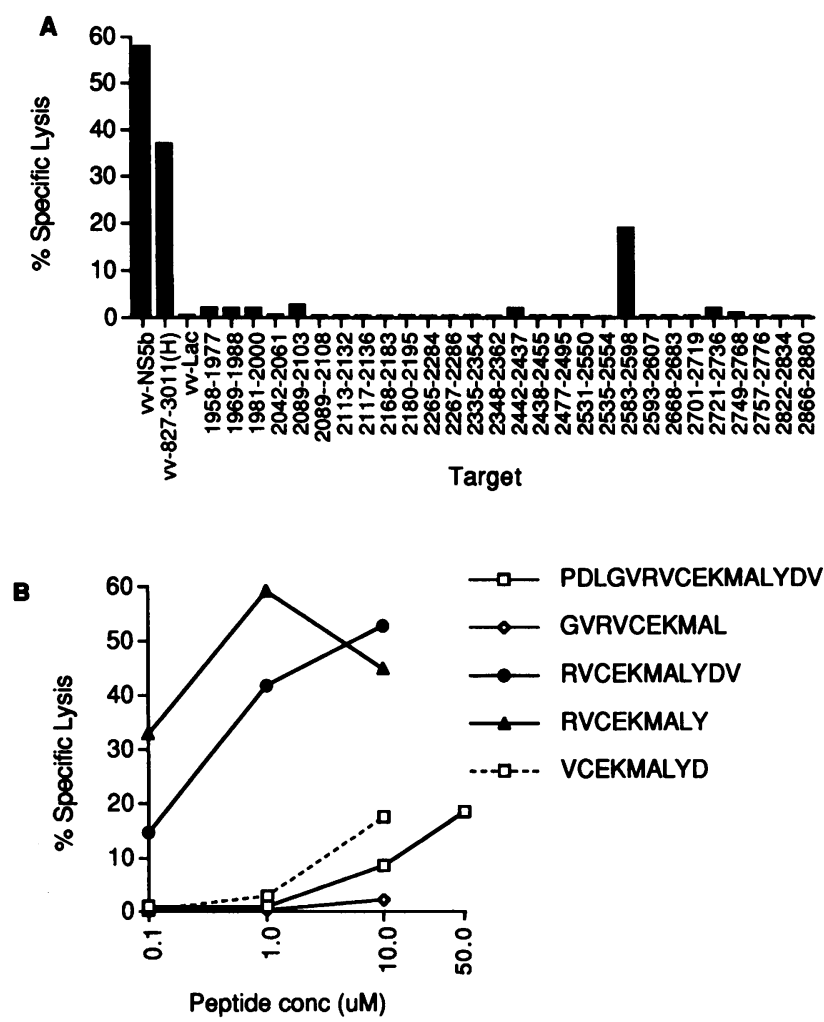

Figure 6. Mapping of the HCV epitope recognized by the HLA A3restricted clone 9I-16. (A) Line 93I-16 was tested for the ability to recognize target cells incubated with synthetic peptides predicted from the NS5B sequence of the $\mathrm{H}$ strain to contain $\mathrm{T}$ cell epitopes on the basis of amphipathicity. Only the peptide spanning aa 2583-2598 (PDLGVRVCEKMALYDV) was able to sensitize target cells for lysis. The E/T was 5:1 and the concentration of peptide used was $20 \mu \mathrm{g} / \mathrm{ml}$. (B) Amino and carboxy terminal truncations of this peptide were tested for their ability to sensitize target cells for lysis. Optimal recognition was achieved with the sequence RVCEKMALY (aa 2588-2596). The $\mathrm{E} / \mathrm{T}$ was $1: 1$

HCV-specific CTL produce multiple cytokines upon recognition of target cells. In murine models of viral hepatitis, cytokines produced by virus-specific CTL may serve as specific inhibitors of viral replication (reviewed in reference 15), yet may also contribute to tissue necrosis by acting as mediators of inflammation (12). Activated macrophages and other cell types may produce large amounts of cytokines (for example, activated macrophages produce large amounts of TNF- $\alpha$; reference 34), but the pattern of cytokine release by CTL is less well characterized, particularly for human CTL. The pattern of cytokine release by murine virus-specific CTL may not correspond to that of human virus-specific CTL (35). In this study, the specific patterns of cytokine release by human HCV-specific CTL in response to recognition of target cells was investigated. For these studies, CTL which grew well and for which the minimum epitope had been precisely defined were used. In addition to the HCV-specific CTL 93I-8 and 93I-58 reported here, lines $92 \mathrm{~N}-47$ and $92 \mathrm{~N}-107$, which have been previously described (4), were used for analysis of cytokine release. Line $92 \mathrm{~N}-47$ recognizes an epitope in $\mathrm{HCV}$ core, aa $41-49$, in the context of HLA B7; and 92N-107 recognizes an epitope in E2, aa 489496 , in the context of HLA B51. For these studies, B-LCL were sensitized with peptide containing the minimal epitope 


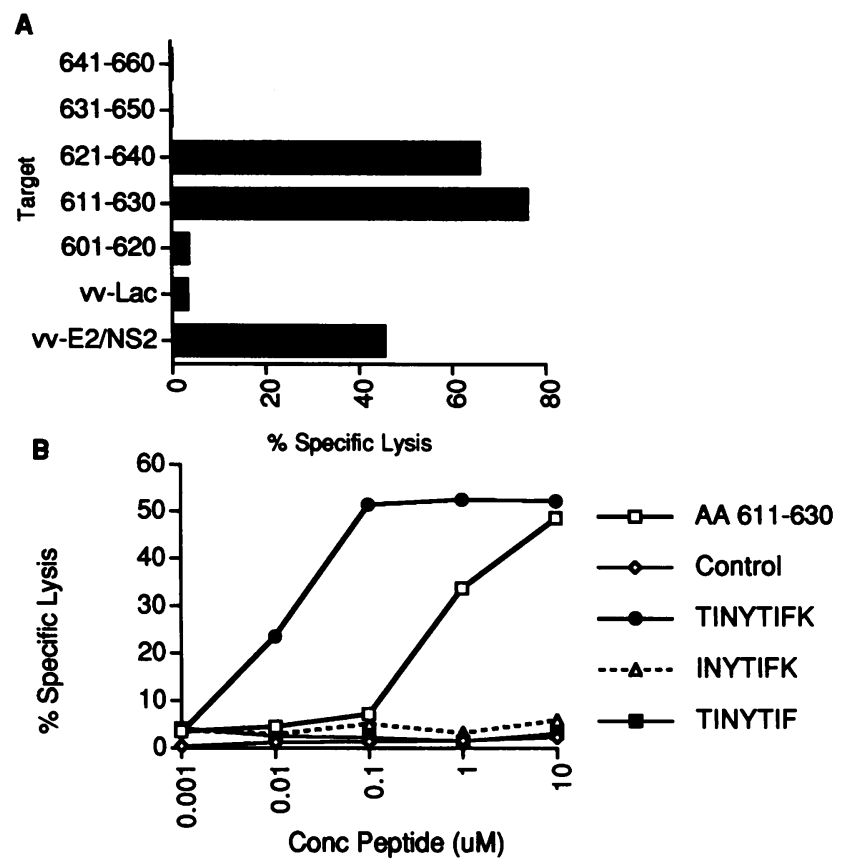

Figure 7. Mapping of the HCV epitope recognized by the HLA A11restricted clone 94F-35. (A) Line 94F-35 was tested for the ability to recognize target cells incubated with overlapping 20 aa peptides spanning the proteins encoded by the recombinant vaccinia virus recognized by this clone, aa 347-966. Only peptides spanning aa 611-630 (YPRLWHYPCTINYTIFKIR) and aa 621-640 (TINYTIFKIRMYVGGVEHRL) were able to sensitize target cells for lysis. The E/T was 5:1, and the concentration of peptide used for sensitization of target cells was $50 \mu \mathrm{g} / \mathrm{ml}$. ( $B$ ) Line $94 \mathrm{~F}-35$ was tested for its ability to lyse autologous target cells autologous cells sensitized with amino and carboxy terminal truncations of aa 620-630, which lie within E2. Serial 10-fold dilutions of peptides in this region were incubated with target cells, and clone 94F-35 was tested for its ability to lyse target cells. The minimum peptide which could sensitize target cells for lysis was TINYTIFK (aa 621-8). A peptide spanning aa 1-7 (MSTNPKP) was used as a negative control. The E/T was 5:1.

recognized by the CTL or a control, irrelevant peptide, irradiated, and then cocultured with the respective CTL at an E/T of 1:1. Additional controls consisted of effector cells and target cells incubated with media alone, effector cells cultured in the presence of conA, and target cells lysed with detergent. The role of HLA antigens in restricting cytokine release by these HCV-specific CTL was investigated using autologous B-LCL, partially HLA-matched B-LCL, and HLA-mismatched B-LCL. Supernatants were harvested at $24 \mathrm{~h}$, at which time cytokine levels were maximal (16). Although use of B-LCL infected with the relevant $\mathrm{HCV}$-recombinant vaccinia virus gave similar results when used as target cells in these assays, peptide-sensitized targets gave higher and more reproducible levels of cytokine release (data not shown).

The HCV E2-specific CTL 92N-107 produced IFN- $\gamma$, TNF$\alpha, \mathrm{IL}-8$, and GM-CSF, and IL-10 only when the target cells displayed an HLA B51 molecule and were sensitized with the epitope recognized by this line, paralleling the restriction observed for the cytolytic activity of these cells (Table III). Production of IL-4 and IL- 6 could not be demonstrated for this line or any other HCV-specific CTL line (data not shown).

Similar, although not identical, patterns of cytokine release were shown with three additional lines, as shown in Table IV.
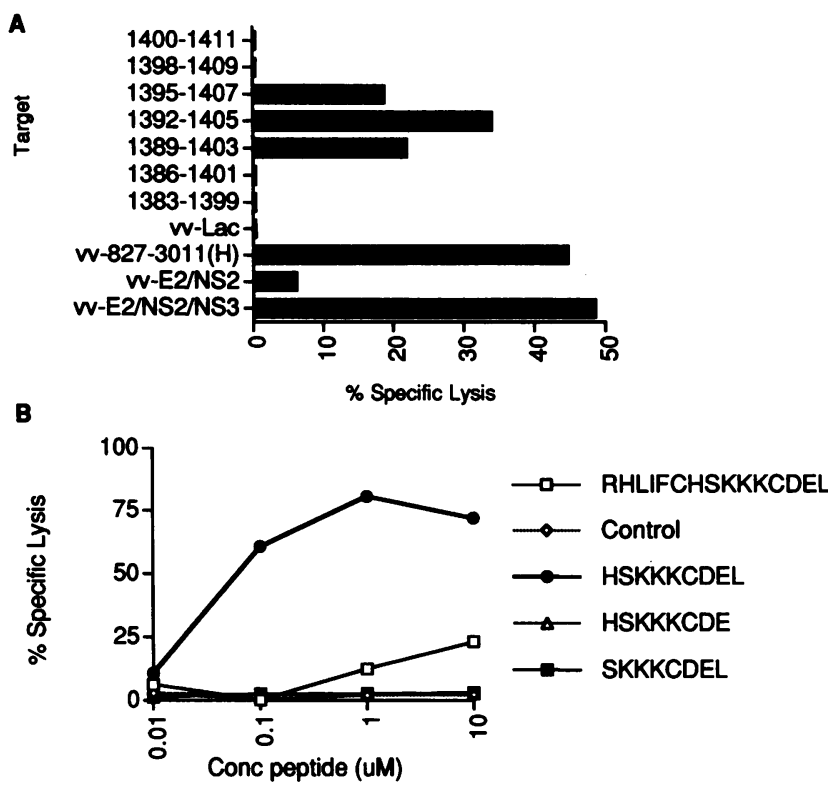

Figure 8. Mapping of the HCV epitope recognized by the HLA B8restricted clone 94F-65. (A) 94F-65 was tested for its ability to lyse target cells sensitized with peptides spanning part of the NS2 and the NS3 protein (aa 827-1619). Synthetic 15 aa peptides which overlapped by 10 aa were available. Only peptides spanning aa 1389-1403 (RHLIFCHSKKKCDEL), aa 1392-1405 (IFCHSKKKCDELAA), and aa 1395-1407 (HSKKKCDELAAKL) sensitized target cells for lysis by this NS3-specific clone. $(B)$ Line $94 \mathrm{~F}-65$ was tested for its ability to lyse target cells sensitized with amino and carboxy terminal truncations of aa 1395-1403. Serial 10-fold dilutions of peptides in this region were incubated with target cells, and clone 94F-65 was tested for its ability to lyse target cells. The minimum peptide which could sensitize target cells for lysis was HSKKKCDEL (aa 1395-1403). A peptide spanning aa 489-496 (YPPKPCGI) was used as a negative control. The E/T was 5:1.

These HCV-specific CTL released IFN- $\gamma$, TNF- $\alpha$, IL-8, and GM-CSF upon recognition of the relevant peptide sensitized target cell, but did not produce IL-10. The ability to detect IL10 after cocultivation of $92 \mathrm{~N}-107$ with target cells expressing B51 and sensitized with the relevant epitope was not related to levels of cytolytic activity, since other lines, such as 93I-58, had a higher level of percent specific cytotoxicity and were negative for IL-10 production in the same cytokine assay. This suggests that there are different subsets of cytolytic cells, although it is possible that production of IL-10 by the other CTL was below the detection limits of the assay used.

\section{Discussion}

The role of cellular immune responses in hepatitis $\mathrm{C}$ virus infection is still in the early stages of characterization. In some viral infections, the response of CD8+ CTL is felt to be limited, with responses against a single protein dominating the CTL response $(32,36,37)$, especially after the acute illness has resolved and the infection has become either chronic or resolved completely (38). However, in HIV-1 infection, which shares the property of extensive sequence heterogeneity with $\mathrm{HCV}$, up to 14 different CTL epitopes have been identified within a single individual (39). In acute HBV infection, up to five HLA A2.1restricted epitopes have been identified within the peripheral blood after a period of in vitro peptide stimulation (9), although 
A

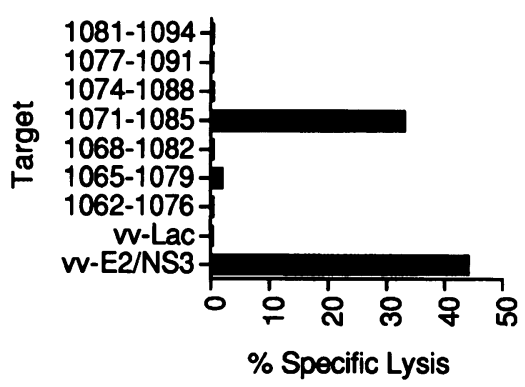

B

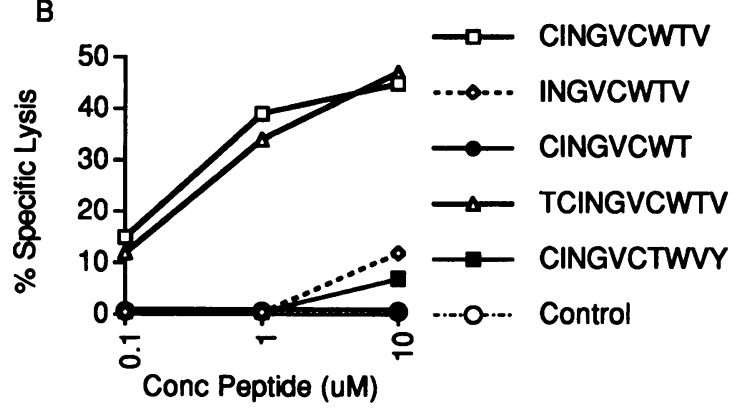

C

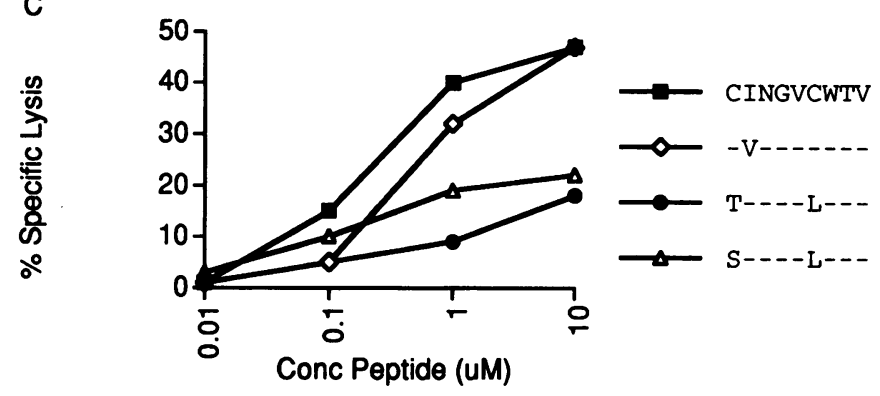

Figure 9. Mapping of the HCV epitope recognized by the HLA A2-restricted clone 93K-33. (A) 93K-33 was tested for its ability to lyse target cells sensitized with peptides spanning the NS3 protein. Synthetic 15 aa peptides which overlapped by 10 aa were available. Only the peptide spanning aa 1071-1085 (CINGVCWTV) sensitized target cells for lysis by this NS3-specific clone. $(B)$ Line 93I-16 was tested for its ability to lyse target cells sensitized with amino and carboxy terminal truncations of aa 1071-

1085. Serial 10-fold dilutions of this region were incubated with target cells, and clone 93I-16 was tested for its ability to lyse target cells. The minimum peptide which could sensitize target cells for lysis was aa 1073-1081 (CINGVCWTV). A peptide spanning aa 489-496 (YPPKPCGI) was

used as a negative control. The E/T was 5:1. (C) Recognition of HCV variants by clone 93K-33. Serial 10-fold dilutions of peptides which reflect natural variants were incubated with target cells, and clone $93 \mathrm{~K}-33$ was tested for its ability to lyse target cells. The E/T was 5:1.

these CTL responses could not be detected in the PBMC of chronically HBV-infected individuals using the same methodology. In this report we identify multiple sites within both structural and nonstructural proteins of $\mathrm{HCV}$ as targets for HCVspecific CTL in chronically infected persons, without the use of exogenous in vitro antigenic stimulation. There have been other reports of HCV-specific CTL in PBMC, which were detected after prolonged periods of in vitro stimulation with synthetic peptides $(40,41)$. However, at least one group has reported the induction of primary in vitro HCV-specific responses in seronegative individuals with this methodology $(41,42)$, and so interpretation of the role of CTL identified following peptide stimulation awaits further study.

With nonspecific stimulation strategies, such as have been used in detecting HIV-1-specific CTL (17) as well as HCVspecific CTL $(4,5)$, it is possible to detect CTL directed against multiple different antigens without influencing the specificities of the CTL in vitro. After expansion of the CD8 + liver-infiltrating lymphocytes in the liver biopsy specimen, we are able to observe responses directed against multiple proteins (in the case of $94 \mathrm{~F}$, five separate epitopes), restricted by a variety of HLA molecules. Since HCV displays considerable sequence hetero-

Table III. HLA B51-restricted Release of Cytokines by the HCV E2-specific CTL Clone 92N-107

\begin{tabular}{|c|c|c|c|c|c|c|c|c|}
\hline \multirow[b]{2}{*}{ Target } & \multirow[b]{2}{*}{ Peptide $^{\ddagger}$} & \multirow[b]{2}{*}{ Effector } & \multirow[b]{2}{*}{$\%$ Lysis $^{8}$} & \multirow[b]{2}{*}{ IFN- $\gamma$} & \multicolumn{2}{|c|}{ Cytokine $(\mathrm{pg} / \mathrm{ml})^{*}$} & \multirow[b]{2}{*}{ IL-8 } & \multirow[b]{2}{*}{ IL-10 } \\
\hline & & & & & TNF- $\alpha$ & GM-CSF & & \\
\hline \multicolumn{9}{|c|}{ Shared HLA } \\
\hline- & & + & & $<31$ & $<25$ & 33 & 0 & $<16$ \\
\hline- & - & $+\operatorname{con} \mathrm{A}$ & & 183 & 127 & 674 & 0 & 107 \\
\hline \multirow[t]{2}{*}{ B51 } & aa $489-496$ & + & 15.9 & 6517 & 4900 & 12,264 & 1050 & 537 \\
\hline & aa $489-496$ & - & & $<31$ & 40 & $<10$ & 0 & 30 \\
\hline \multirow[t]{3}{*}{ Lysed" } & none & - & & $<31$ & $<25$ & $<10$ & & $<16$ \\
\hline & aa $41-49$ & + & 0.5 & 45 & 25 & 27 & 10 & $<16$ \\
\hline & aa $41-49$ & - & & $<31$ & 40 & 12 & 0 & $<16$ \\
\hline \multirow[t]{4}{*}{ None } & aa $489-496$ & + & 0.6 & $<31$ & $<25$ & 25 & 0 & 20 \\
\hline & aa $489-496$ & - & & $<31$ & 35 & $<10$ & 0 & 28 \\
\hline & aa 41-49 & + & 0.1 & $<31$ & 35 & 24 & 0 & $<16$ \\
\hline & aa $41-49$ & - & & $<31$ & $<25$ & $<10$ & 0 & $<16$ \\
\hline
\end{tabular}

Cytokine release was measured after a 24-h coincubation of the core-specific CTL clone 92N-47 and irradiated B-LCL sensitized with either the epitope recognized by this CTL clone (YPPKPCGI, aa 489-496) or an irrelevant control peptide (GRLGVRAT, aa 41-49). No autologous cell line was available for this subject, and so target cells shared either a B51 molecule or were mismatched across all class I and II loci. * E/T 1:1, measured at $24 \mathrm{~h}$. ${ }^{\ddagger}$ Target cells were sensitized with either the CTL epitope (aa 489-496) or an irrelevant peptide (aa 41-49) and irradiated with $100 \mathrm{~Gy} .{ }^{8} \mathrm{E} / \mathrm{T}$ 1:1, measured at $4 \mathrm{~h}$. " B51-expressing target cells and effector cells were lysed at $24 \mathrm{~h}$. 


\begin{tabular}{|c|c|c|c|c|c|c|c|c|}
\hline \multirow[b]{2}{*}{ CTL } & \multirow[b]{2}{*}{ Target $^{\ddagger}$} & \multirow[b]{2}{*}{ Peptide } & \multirow[b]{2}{*}{ \% Lysis ${ }^{8}$} & \multirow[b]{2}{*}{ IFN- $\gamma$} & \multicolumn{2}{|c|}{ Cytokine $(\mathrm{pg} / \mathrm{ml})^{*}$} & \multirow[b]{2}{*}{ IL-8 } & \multirow[b]{2}{*}{ IL-10 } \\
\hline & & & & & TNF- $\alpha$ & GM-CSF & & \\
\hline \multirow[t]{2}{*}{ 93I-8 } & Autol & aa $831-850$ & 23.4 & 250 & 406 & 120 & 75 & $<16$ \\
\hline & Autol & aa $1-20$ & 0.1 & $<31$ & $<25$ & $<10$ & 0 & $<16$ \\
\hline \multirow[t]{5}{*}{ 93I-58" } & Autol & aa $41-49$ & 54.8 & 25,000 & 2200 & 16,000 & 3750 & $<16$ \\
\hline & Autol & aa $483-492$ & -1.4 & 65 & $<25$ & $<10$ & 0 & $<16$ \\
\hline & B7 & aa $41-49$ & 59.1 & 25,000 & 1900 & 2600 & 4000 & $<16$ \\
\hline & B7 & aa $483-492$ & 2.1 & 55 & $<25$ & $<10$ & 0 & $<16$ \\
\hline & No match & aa $41-49$ & 0.8 & 125 & $<25$ & $<10$ & 0 & $<16$ \\
\hline \multirow[t]{5}{*}{$92 \mathrm{~N}-47$} & B7 & aa $41-49$ & 29.0 & 1051 & 3980 & 1080 & 691 & $<16$ \\
\hline & B7 & aa $483-492$ & 0.2 & 43 & $<25$ & $<10$ & 0 & $<16$ \\
\hline & No match & aa $41-49$ & 0.2 & 60 & $<25$ & $<10$ & 0 & $<16$ \\
\hline & No match & aa $483-492$ & 0.0 & 46 & $<25$ & $<10$ & 0 & $<16$ \\
\hline & None & $\operatorname{con} \mathrm{A}$ & - & 391 & 391 & 142 & 51 & $<16$ \\
\hline
\end{tabular}

Cytokine release was measured after a 24-h coincubation of the HCV-specific CTL clone and autologous B-LCL sensitized with either the epitope recognized by the clone or an irrelevant control peptide. Autologous B-LCL were sensitized before the coincubation with the indicated peptide and then irradiated with $100 \mathrm{~Gy}$ in a gamma irradiator. In addition to coincubation of the CTL clone with B-LCL sensitized with both relevant and irrelevant peptides, cytokine release was also measured after a 24-h incubation of the B-LCL sensitized with the peptides as well as the clone alone without the addition of target cells. Cytokine release was below the limit of detection for the ELISA assays for these controls (data not shown). * E/T 1:1, measured at $24 \mathrm{~h}$. ${ }^{\ddagger}$ CTL 93I-8 recognized target cells sensitized with a synthetic peptide corresponding to aa 831-850, and aa 1-20 served as a negative control. CTL 93I-58 recognized target cells sensitized with a synthetic peptide corresponding to aa 41-49, and aa 483-492 served as a negative control. CTL $92 \mathrm{~N}-47$ also recognized target cells sensitized with a synthetic peptide corresponding to aa 41-49, and aa 483492 was also used as a control. An autologous B-LCL was not available for subject 92N, and so target cells shared a B7 molecule or were mismatched across all class I and II loci (4). ${ }^{\S} \mathrm{E} / \mathrm{T} \mathrm{1:1,} \mathrm{measured} \mathrm{at} 4 \mathrm{~h}$. " The complete HLA type of subject 93I is A2, 23; B 7, 53: C4,5: DR 8,13: DRw52, DQ 1,7.

geneity among isolates, with at least six major genotypes of virus $(43,44)$, it is possible that our results actually underestimate the spectrum and frequency of HCV-specific CTL responses in these chronically infected individuals. We are limited by the number of genotypes of HCV which are currently expressed in vaccinia virus recombinants. In this report we identify CTL responses which were cross-reactive (e.g., 94F-69) as well as isolate specific (e.g., 93I-16) were observed. The failure to identify CTL in the other subjects studied may be caused by one or more of the following: the absence of $\mathrm{HCV}$-specific CTL in these individuals; the presence of HCV-specific CTL which recognize another strain of $\mathrm{HCV}$ and do not recognize either HCV-1 or the H strain; or the loss of cells present at a low frequency during either the period of in vitro expansion or the subsequent cloning. At present, given the limited number of $\mathrm{HCV}$ isolates which are expressed in vv, we cannot determine the major reason leading to a failure to identify $\mathrm{HCV}$-specific CTL in these other individuals. A similar frequency of HCVspecific responses was detected in PBMC of HCV seropositive individuals after prolonged in vitro stimulation with synthetic peptides (41).

Several lines of evidence have aided in the definition of epitopes recognized by virus-specific CTL. The first has come from extensive fine mapping studies of CTL epitopes performed in a number of laboratories, which permitted the prediction of motifs based on sequence similarities among epitopes recognized in the context of a given HLA molecule (reviewed in reference 33). Allele-specific motifs have been proposed for several murine and human HLA types, including HLA A2, B27, A3, and B8 (45). More recently, the ability to elute naturally processed peptides from the surface of naturally infected cells has confirmed the utility of this technique in the characterization of epitopes recognized by CTL (46). The epitopes recognized by these HCV-specific CTL conform to proposed motifs, although we have also identified CTL epitopes restricted by HLA for which a peptide binding motif has not yet been proposed. For example, the HLA B7 motif is proposed to consist of a proline at position 2 , arginine at position 3 , and a leucine or valine at position 9 (47). The epitope recognized by the HLA B7-restricted CTL 93I-58, GPRLGVRAT, is consistent with this motif, with the exception being the nonconservative substitution of a threonine at position 9. Similarly, the epitope recognized by the HLA B8-restricted CTL 94F-65 HSKKKCDEL, is consistent with the proposed motif for HLA B8, which is a lysine at position 3 , lysine or arginine at position 5 , and a carboxy terminal isoleucine or leucine (32).

Since HCV is a highly heterogeneous virus and these epitopes are present within both conserved and variable regions of the genome, precise definition of the epitopes recognized by HCV-specific CTL may allow an understanding of the effect of sequence variation on the immune response to $\mathrm{HCV}$. Although some aa substitutions within the middle of the CTL epitope-binding site may not affect binding of the peptide to the class I molecule (48), other groups have shown that even single aa variations within CTL epitopes facilitates viral escape from host immunity $(49,50)$. In addition to a failure of CTL to recognize variant sequences present within an epitope, several groups have recently shown that natural variants within CTL epitopes may act as antagonists to $\mathrm{T}$ cell receptor binding $(51,52)$.

Whatever the role of $\mathrm{HCV}$-specific CTL in controlling viral replication, viremia persists despite the presence of a cellular immune response in chronically infected individuals. In such circumstances, CTL may contribute to disease pathogenesis, 
and evidence is accumulating that cytokines may be important mediators of this immunopathology. Recent data have shown that adoptive transfer of $\mathrm{HBV}$-specific CTL into $\mathrm{HBsAg}$ transgenic mice led to liver cell necrosis (53). This tissue damage is due to direct cell lysis by the CTL (35), with amplification of liver necrosis by cytokines such as IFN- $\gamma$ and TNF- $\alpha$ (12). The initial response appears to consist of an antigenspecific response by virus-specific CTL, followed by production of IFN- $\gamma$ and TNF- $\alpha$. This, in turn, leads to antigen-nonspecific recruitment of inflammatory cells, followed by activation of macrophages and a delayed-type hypersensitivity like lesion. Blockade of the cascade of events occurs when animals are pretreated with antibodies to TNF- $\alpha$ before adoptive transfer of HBV-specific CTL (12). In another transgenic mouse model, liver-specific expression of IFN- $\gamma$ produced a transaminitis and histologic appearance similar that of human chronic active hepatitis (54).

In addition to the effects of IFN- $\gamma$ and TNF- $\alpha$, other cytokines are produced by these human virus-specific CTL. Although the role of these cytokines has not yet been investigated in animal models, the known biologic actions of these cytokines suggest that these cytokines might also play a role in the pathogenesis of chronic hepatitis. Both GM-CSF and IL-8 lead to a recruitment of inflammatory cells (55). IL-10 may be produced by certain classes of CD4 cells (14), and it has been well demonstrated in murine models that two types of CD4 lymphocytes populations may be defined based on production of IFN$\gamma$ and IL-10 (56). However, production of IL-10 by virusspecific cytolytic T cells has not been reported. IL-10 is thought to be a down-regulator of immune responses (57), and so production of this cytokine by CTL might contribute to viral persistence.

Heterogeneous production of cytokines by melanoma-specific CD8 + CTL has also been observed (58), which may be due to different populations of CD8 + CTL or methodologic issues relating to the method of $\mathrm{T}$ cell stimulation. For example, it is unknown whether virus-specific CTL have a different pattern of cytokine release than tumor-specific CTL, although on the basis of these two studies this would seem unlikely. In most instances the precise targets of the cytolytic response have not been defined and production of cytokines has been measured after stimulation with immobilized anti-CD3, which has not always resulted in the same pattern of cytokine release as stimulation with the specific antigen recognized by the CTL (58) For example, stimulation of murine CD8+ cells with an antiCD3 antibody resulted in the production of Il-10 only in $T_{s}$ cells, but not in CTL (59).

In addition, characterization of responses produced by CTL isolated from the periphery might have a different pattern of cytokine release compared to those isolated from the site of tissue damage. This tissue-specific compartmentalization of cytokine release has recently been demonstrated for CD4+ cytolytic cells isolated from the liver of patients with chronic HBV infection (60). We have previously demonstrated the compartmentalization of HCV-specific CTL within the liver (4). To date we have not be able to isolate $\mathrm{HCV}$-specific CTL within the PBMC using an antigen nonspecific stimulation strategy, and so we have not had the opportunity to compare liver-infiltrating versus PBMC-derived $\mathrm{HCV}$-specific CTL for the patterns of cytokine release. However, if chronic HCV hepatitis is a $\mathrm{T}$ cell-mediated disease, knowledge of cytokines produced by the cells which induce the inflammatory cascade, as well as the precise targets recognized by these CTL, may suggest novel immunotherapeutic interventions.

\section{Acknowledgments}

We would like to thank Dr. David Nunes for assistance in providing patient material; Dr. Bob Ralston for the gift of vaccinia-HCV recombinant viruses; Kent Thudium, Kim Berger, and Christine Dong for expert technical assistance; Dr. M. Gately of Hoffmann-LaRoche for the gift of rIL-2; Donna Fitzpatrick and the MGH Tissue Typing Laboratory for assistance in HLA typing; and Dr. Johnson Wong for the gift of the anti-CD3 antibody $12 \mathrm{~F} 6$ and the bispecific antibody CD3,4B.

These studies were supported by an American Cancer Society Physician's Research Training Award and an National Institutes of Health Clinical Investigator Award (M.J. Koziel), and by National Institutes of Health grants AI31563 (B.D. Walker) and CA57973 (C.M. Rice).

\section{References}

1. Lemon, S., and E. Brown. 1994. Hepatitis C virus and chronic liver disease. In Current Clinical Topics in Infectious Disease. Vol. 14. M. N. Swartz and J. S. Remington, editors New York. 121-141.

2. Alter, M. J., H. S. Margolis, K. Krawczynski, F. Judson, A. Mares, W. Alexander, P.-Y. Hu, J. K. Miller, M. A. Gerber, and R. E. Sampliner. 1992. The natural history of community-acquired hepatitis $\mathrm{C}$ in the United States. $N$. Engl. J. Med. 327:1899-1905.

3. Shimizu, Y. K., M. Hijikata, A. Iwamoto, H. J. Alter, R. H. Purcell, and H. Yoshikura. 1994. Neutralizing antibodies against hepatitis $\mathrm{C}$ virus and the emergence of neutralization escape mutant viruses. J. Virol. 68:1494-1500.

4. Koziel, M. J., D. Dudley, N. Afdhal, Q.-L. Choo, M. Houghton, R. Ralston and B. Walker. 1993. Hepatitis C virus-specific cytotoxic T lymphocytes recognize epitopes in the core and envelope proteins of HCV. J. Virol. 67:7522-7532.

5. Koziel, M. J., D. Dudley, J. Wong, J. Dienstag, M. Houghton, R. Ralston, and B. D. Walker. 1992. Intrahepatic cytotoxic T lymphocytes specific for hepatitis C virus in persons with chronic hepatitis. J. Immunol. 149:3339-3344.

6. Minutello, M. A., P. Pileri, D. Unutmaz, S. Censini, G. Kuo, M. Houghton, M. R. Brunetto, F. Bonino, and S. Abrignani. 1993. Compartmentalization of lymphocytes to the site of disease: intrahepatic CD4+ T cells specific for the protein NS4 of hepatitis C virus in patients with chronic hepatitis C. J. Exp. Med. 178:17-25.

7. Botarelli, P., M. R. Brunetto, M. A. Minutello, P. Calvo, D. Unutmaz, A. J. Weiner, Q. L. Choo, J. R. Shuster, G. Kuo, F. Bonino, et al. 1993. T-lymphocyte response to hepatitis $\mathrm{C}$ virus in different clinical courses of infection. Gastroenterology. 104:580-587.

8. Penna, A., F. V. Chisari, A. Bertoletti, G. Missale, P. Fowler, T. Giuberti, F. Fiaccadori, and C. Ferrari. 1991. Cytotoxic T lymphocytes recognize an HLAA2-restricted epitope within the hepatitis B virus nucleocapsid antigen. $J$. Exp. Med. 174:1565-1570.

9. Nayersina, R., P. Fowler, S. Giulhot, G. Missale, A. Cerny, H.-J. Schlicht A. Vitiello, R. Chesnut, J. Person, A. Redecker, and F. Chisari. 1993. HLA A2 restricted cytotoxic $T$ lymphocyte responses to multiple hepatitis $B$ surface antigen epitopes during hepatitis B virus infection. J. Immunol. 150:4659-4671.

10. Mondelli, M., M. Manns, and C. Ferrari. 1988. Does the immune response play a role in the pathogenesis of chronic liver disease? Arch. Pathol. Lab Med. 112:489-497.

11. Di-Bisceglie, A. M., J. H. Hoofnagle, and K. Krawczynski. 1993. Changes in hepatitis C virus antigen in liver with antiviral therapy. Gastroenterology. 105:858-862.

12. Ando, K., T. Moriyama, L. Guidotti, S. Wirth, R. Schreiber, S. HansJurgen, S.-n. Huang, and F. Chisari. 1993. Mechanisms of class I restricted immunopathology. A transgenic mouse model of fulminant hepatitis. J. Exp. Med. 178:1541-1554.

13. Guidotti, L. G., K. Ando, M. V. Hobbs, T. Ishikawa, L. Runkel, R. D. Schreiber, and F. V. Chisari. 1994. Cytotoxic T lymphocytes inhibit hepatitis B virus gene expression by a noncytolytic mechanism in transgenic mice. Proc. Natl. Acad. Sci. USA. 91:3764-3768.

14. Mosmann, T. R., J. H. Schumacher, N. F. Street, R. Budd, A. O. Garra, T. A. Fong, M. W. Bond, K. W. Moore, A. Sher, and D. F. Fiorentino. 1991 Diversity of cytokine synthesis and function of mouse CD4+ T cells. Immunol. Rev. 123:209-229.

15. Ramsay, A. J., J. Ruby, and I. A. Ramshaw. 1993. A case for cytokines as effector molecules in the resolution of virus infection. Immunol. Today. 14:155157

16. Jassoy, C. J., T. Harrer, T. Rosenthal, B. A. Navia, J. Worth, R. P. Johnson, and B. D. Walker. 1992. HIV-1-specific cytotoxic $\mathrm{T}$ cells release interferon gamma, tumor necrosis factor (TNF)-alpha and TNF-beta when they encounter their target antigens. J. Virol. 67:2844-2852. 
17. Walker, B. D., C. Flexner, K. Birch-Limberger, L. Fisher, T. J. Paradis, A. Aldovini, R. Young, B. Moss, and R. T. Schooley. 1989. Long-term culture and fine specificity of human cytotoxic T-lymphocyte clones reactive with human immunodeficiency virus type 1. Proc. Natl. Acad. Sci. USA. 86:9514-9518.

18. Spaete, R., A. D'Anna, M. Rugroden, Q.-L. Choo, K. Berger, K. Crawford C. Kuo, S. Leng, C. Lee, R. Ralston, et al. 1992. Characterization of the hepatitis C virus E2/NS1 gene product expressed in mammalian cells. Virology. 188:819830.

19. Ralston, R., K. Thudium, K. Berger, C. Kuo, B. Gervase, J. Hall, M Selby, G. Kuo, M. Houghton, and Q. L. Choo. 1993. Characterization of hepatitis C virus envelope glycoprotein complexes expressed by recombinant vaccinia viruses. J. Virol. 67:6753-6761.

20. Grakoui, A., C. Wychowski, C. Lin, S. Feinstone, and C. Rice. 1993 Expression and identification of hepatitis $\mathrm{C}$ virus polyprotein cleavage products. J. Virol. 67:1385-1395.

21. Chakrabati, S., K. Brechling, and B. Moss. 1985. Vaccinia virus expression vector: Coexpression of $\beta$-galactosidase provides visual screening of recombinant virus plaques. Mol. Cell Biol. 5:3403-3409.

22. Grakoui, A., D. W. McCourt, C. Wychowski, S. M. Feinstone, and C. M. Rice. 1993. Characterization of the hepatitis $C$ virus-encoded serine proteinase determination of proteinase-dependent polyprotein cleavage sites. J. Virol. 67:2832-43.

23. Choo, Q.-L., K. H. Richman, J. H. Han, K. Berger, C. Lee, C. Dong, C. Gallegos, D. Coit, A. Medina-Selby, P. J. Barr, et al. 1991. Genetic organization and diversity of the hepatitis C virus. Proc. Natl. Acad. Sci. USA. 88:2451-2455.

24. Atherton, E., and R. Sheppard. 1989. Solid Phase Peptide Synthesis. Oxford University Press, Oxford. 203 pp.

25. Shirai, M., T. Akatsuka, C. D. Pendleton, R. Houghten, C. Wychowski, K. Mihalik, S. Feinstone, and J. A. Berzofsky. 1992. Induction of cytotoxic T cells to a cross-reactive epitope in the hepatitis $\mathrm{C}$ virus nonstructural RNA polymerase-like protein. J. Virol. 66:4098-4106.

26. Wong, J. T., and R. Colvin. 1987. Bispecific monoclonal antibodies: selective binding and complement fixation to cells that express two differen surface antigens. J. Immunol. 139(4):1369-1374.

27. Walker, B. D. 1990. HIV-1-specific cytotoxic T lymphocytes. In Techniques in HIV Research. A. Aldovini and B. D. Walker, editors. Stockton Press, New York. 201-209.

28. Zinkernagel, R., and P. Doherty. 1979. MHC-restricted cytotoxic T cells: studies on the biological role of polymorphic major transplantation antigens determining T-cell restriction-specificity, function, and responsiveness. Adv. Immunol. 27:51-177.

29. Townsend, A. R., J. Rothbard, F. M. Gotch, G. Bahadur, D. Wraith, and A. J. McMichael. 1986. The epitopes of influenza nucleoprotein recognized by cytotoxic $\mathrm{T}$ lymphocytes can be defined with short synthetic peptides. Cell. 44:959-968.

30. Margalit, H., J. L. Spouge, J. L. Cornette, K. B. Cease, C. Delisi, and J. A. Berzofsky. 1987. Prediction of immunodominant T cell antigenic sites from the primary sequence. J. Immunol. 138:2213-2229.

31. DiBrino, M., K. Parker, J. Shiloach, M. Knierman, J. Lukszo, R. Turner, W. Biddison, and J. Coligan. 1993. Endogenous peptides bound to HLA-A3 possess a specific combination of anchor residues that permit identification of potential antigenic peptides. Proc. Natl. Acad. Sci. USA. 90:1508-1512.

32. Sutton, J., S. Rowland-Jones, W. Rosenberg, D. Nixon, F. Gotch, X. M Gao, N. Murray, A. Spoonas, P. Driscoll, and M. Smith. 1993. A sequence pattern for peptides presented to cytotoxic T lymphocytes by HLA B8 revealed by analysis of epitopes and eluted peptides. Eur. J. Immunol. 23:447-53.

33. Falk, K., and H.-G. Ramensee. 1993. Consensus motifs and peptide ligands of MHC class I molecules. Semin. Immunol. 5:81-94.

34. Gonzalez-Amaro, R., C. Garcia-Monzon, L. Garcia-Buey, R. MorenoOtero, J. L. Alonso, E. Yague, J. P. Pivel, M. Lopez-Cabrera, E. Fernandez-Ruiz, and F. Sanchez-Madrid. 1994. Induction of tumor necrosis factor alpha production by human hepatocytes in chronic viral hepatitis. J. Exp. Med. 179:841-848.

35. Ando, K., L. Guidotti, S. Wirth, T. Ishikawa, G. Missale, T. Moriyama, R. Schreiber, H. J. Schlicht, S. Huang, and F. Chisari. 1994. Class I-restricted cytotoxic $\mathrm{T}$ lymphocytes are directly cytopathic for their target cells in vivo. $J$. Immunol. 152:3245-3253.

36. Gotch, F., A. McMichael, G. Smith, and B. Moss. 1986. Identification of viral molecules recognized by influenza-specific human cytotoxic $\mathrm{T}$ lymphocytes J. Exp. Med. 165:408.

37. de Campos-Lima, P. O., V. Levitsky, J. Brooks, S. P. Lee, L. F. Hu, A. B. Rickinson, and M. Masucci. 1994. T cell responses and virus evolution: loss of HLA A11-restricted CTL epitopes in Epstein-Barr virus isolates from highly A11-positive populations by selective mutation of anchor residues. J. Exp. Med. 179:1297-1305.

38. Penna, A., F. Chisari, A. Bertoletti, G. Missale, P. Fowler, T. Giuberti, F.
Fiaccadori, and C. Ferrari. 1991. Cytotoxic T cells recognize an HLA-A2-restricted epitope within the hepatitis B virus nucleocapsid antigen. J. Exp. Med. 174:1565-1570.

39. Johnson, R. P., and B. D. Walker. 1994. Cytotoxic T lymphocytes in human immunodeficiency virus infection: responses to structural proteins. Curr. Top. Microbiol. Immunol. 189:35-63.

40. Kita, H., T. Moriyama, T. Kaneko, I. Harase, M. Nomura, H. Miura, I Nakamura, Y. Yazaki, and M. Imawari. 1993. HLA B44-restricted cytotoxic T lymphocytes recognizing an epitope on hepatitis $\mathrm{C}$ virus nucleocapsid protein. Hepatology. 18:1039-1044

41. Cerny, A., J. G. McHutchison, C. Pasquinelli, M. E. Brown, M. A. Brothers, B. Grabscheid, P. Fowler, M. Houghton, and F. V. Chisari. 1995. Cytotoxic T lymphocyte response to hepatitis $\mathrm{C}$ virus-derived peptides containing the HLA A2.1 binding motif. J. Clin. Invest. 95:521-530.

42. Cerny, A., P. Fowler, M. A. Brothers, M. Houghton, H. J. Schlicht, and F. V. Chisari. 1995. Induction in vitro of a primary human antiviral cytotoxic T cell response. Eur. J. Immunol. 25:627-630.

43. Simmonds, P., E. C. Holmes, T.-A. Cha, S.-W. Chan, F. McOmish, B Irvine, E. Beall, P. L. Yap, J. Kolberg, and M. Urdea. 1993. Classification of hepatitis $\mathrm{C}$ virus into six major genotypes and a series of subtypes by phylogenetic analysis of the NS-5 region. J. Gen. Virol. 74:2391-2399.

44. Bukh, J., R. Purcell, and R. Miller. 1993. At least 12 genotypes of hepatitis $\mathrm{C}$ virus predicted by sequence analysis of the putative $\mathrm{E} 1$ gene of isolates collected worldwide. Proc. Natl. Acad. Sci. USA. 90:8234-8238.

45. McMichael, A. J., and B. D. Walker. 1994. Cytotoxic T cell epitopes: implications for HIV vaccines. AIDS (Phila.). 8 (Suppl. 1):S155-S173.

46. Falk, K., O. Rötzschke, S. Stevanovic, G. Jung, and H.-G. Rammensee. 1991. Allele-specific motifs revealed by sequencing of self-peptides eluted from MHC molecules. Nature (Lond.). 351:290-296.

47. Englehard, V. H., E. L. Huczko, and W. Bodener. 1993. Peptides bound to HLA-B7 determined by mass spectrometry. J. Cell Biochem. Suppl. 17C:56a (Abstr.).

48. Madden, D. R., D. Garboczi, and D. Wiley. 1993. The antigenic identity of peptide-MHC complexes: a comparison of the conformations of five viral peptides presented by the HLA-A2. Cell. 75:693-708.

49. Aebischer, T., D. Moskophidis, U. Rohrer, R. Zinkernagel, and H. Hengartner. 1991. In vitro selection of lymphocytic choriomeningitis escape mutants by cytotoxic T lymphocytes. Proc. Natl. Acad. Sci. USA. 88:11047-11051.

50. de Campos-Lima, P.-O., R. Gavioli, Q.-J. Zhang, L. Wallace, R. Dolcetti, M. Rowe, A. B. Rickinson, and M. G. Masucci. 1993. HLA-A11 epitope loss isolates of Epstein-Barr virus from a highly A11+ population. Science (Wash DC). 260:98-100.

51. Bertoletti, A., A. Sette, F. Chisari, A. Penna, M. Levrero, M. De Carli, F. Fiaccadori, and C. Ferrari. 1994. Natural variants of cytotoxic epitopes are T-cell receptor antagonists for antiviral cytotoxic T cells. Nature (Lond.). 369:407-410.

52. Klenerman, P., S. Rowland-Jones, S. McAdam, J. Edwards, S. Daenke, D. Lalloo, B. Köppe, W. Rosenberg, D. Boyd, A. Edwards, et al. 1994. Cytotoxic T-cell activity antagonized by naturally occurring HIV-1 gag variants. Nature (Lond.).369:403-407.

53. Moriyama, T., S. Guilhot, K. Klopchin, B. Moss, C. Pinkert, R. Palmiter, R. Brinster, O. Kanagawa, and F. Chisari. 1990. Immunobiology and pathogenesis of hepatocellular injury in transgenic mice. Science (Wash. DC). 248:361-364.

54. Toyonaga, T., O. Hino, S. Sugai, S. Wakasugi, K. Abe, M. Shichiri, and K.-I. Yamamura. 1994. Chronic active hepatitis in transgenic mice expressing intereron- $\gamma$ in the liver. Proc. Natl. Acad. Sci. USA. 91:614-618.

55. Baggiolini, M. 1993. Novel aspects of inflammation: interleukin- 8 and related chemotactic cytokines. Clin. Investig. 71:812-814.

56. Salgame, P., J. Abrams, C. Clayberger, H. Goldstein, J. Convit, R. Modlin, and B. Bloom. 1991. Differing lymphokine profiles of functional subsets of human CD4 and CD8 T cell clones. Science (Wash. DC). 254:279-281.

57. Kurilla, M. G., S. Swaminathan, R. M. Welsh, E. Kieff, and R. R. Brutkiewicz 1993. Effects of virally expressed interleukin-10 on vaccinia virus infection in mice. J. Virol. 67:7623-7628.

58. Maccalli, C., R. Mortarini, G. Parmiani, and A. Anichini. 1994. Multiple sub-sets of CD4 + and CD8 + cytotoxic T-cell clones directed to autologous human melanoma identified by cytokine profiles. Int. J. Cancer. 57:56-62.

59. Inoue, T., Y. Asano, S. Matsuoka, S. M. Furutani, S. Aizawa, H. Nishimura, T. Shirai, and T. Tada. 1993. Distinction of mouse CD8+ suppressor effector $\mathrm{T}$ cell clones from cytotoxic $\mathrm{T}$ cell clones by cytokine production and CD45 isoforms. J. Immunol. 150:2121-2128.

60. Barnaba, V., A. Franco, M. Paroli, R. Benvenuto, G. De-Petrillo, V. L. Burgio, I. Santilio, C. Balsano, M. S. Bonavita, G. Cappelli, et al. 1994. Selective expansion of cytotoxic $\mathrm{T}$ lymphocytes with a CD4+CD56+ surface phenotype and a $\mathrm{T}$ helper type 1 profile of cytokine secretion in the liver of patients chronically infected with hepatitis B virus. J. Immunol. 152:3074-3087. 